\title{
Preliminary Exploration of Copper Minerals in Jebal Barez Mountains, Iran
}

\author{
Mohammad Yousef Mahmoodi*, Abbas Bahroudi, Mansour Ghorbani, Mehran Arian \\ Department of Geology, Science and Research Branch, Islamic Azad University, Tehran, Iran \\ Email: *mahmoodi.y1344@yahoo.com
}

Received March 10, 2013; revised April 10, 2013; accepted May 10, 2013

Copyright (C) 2013 Mohammad Yousef Mahmoodi et al. This is an open access article distributed under the Creative Commons Attribution License, which permits unrestricted use, distribution, and reproduction in any medium, provided the original work is properly cited.

\begin{abstract}
Urumieh-Dokhtar Magmatic Arc (UDMA) is known as a belt with copper and some other metal deposits. The study area is a part of Jebal Barez Mountains located in southeastern of the belt in Iran. Two types of deposits are known in the belt. Semicircular patterns of altered rocks associated with Eocene to Miocene intrusive rocks are known as porphyry copper deposits and linear altered rock patterns associated with extensive faults or dikes indicate potential epithermal or polymetalic vein deposits. In order to clarify the relationship between faults and mineralization, at first alteration zones have been mapped by using remote sensing methods. Then by geological maps and satellites images, most of faults have been revealed and mapped. Based on calculated photolineament factors in smaller districts, a contouring map was drawn. Although assumed faults are pathways for hydrothermal fluid, in regional scale because of difference of geometry, kinematic and timing of faults, all of them have not the same value for mineralization but insist on density of faults and value of photolineament factors can be more useful for preliminary exploration of copper minerals.
\end{abstract}

Keywords: Urumieh-Dokhtar; Alteration Minerals; Remote Sensing; Photolineament Factor; Fracture

\section{Introduction}

Field observations in Jebal Barez Mountains indicate existence of a few copper deposits in feature of porphyry or vein systems. The aims of this paper are:

1) Definition of alteration zones related to copper mineralization.

2) Definition of porphyry and vein copper deposits depend on the shape and patterns of alteration zones.

3) Mapping faults of study area by using geological maps and satellites images.

4) Comparing alteration patterns with fault traces on regional geological maps.

5) Making a contouring map of Photolineament Factor based on Hardcastle method [1] to use as a data layer for tracing a map of probable copper deposits.

\section{Geological Setting}

Urumieh-Dokhtar magmatic belt with NW-SE trending is classified as an Andean type magmatic arc [2,3]. The northwestern part of the belt is the product of Neotethys oceanic plate subduction under the microcontinent of Iran followed by continent-to-continent collision of the

${ }^{*}$ Corresponding author.
Arabian and Eurasian plates. Collision has occurred in late Eocene [4]. Quaternary volcanic rock of the Bazman in southeastern part of the magmatic belt is the product of active subduction that continues along the Makran subduction zone [5]. The northwest collision and southeast subduction zones of the magmatic belt are separated by a convergent transfer zone and Sabzevaran and Gowk strike-slip fault systems (Figure 1) which are part of the Jebal Barez Mountains [6]. The transform zone contains highly faulted Eocene and Oligocene rhyolites, dacites and andesites. Intrusive rocks consist of Oligocene diorites, granodiorites and granite that formed in few different magmatic phases.

In Jebal Barez Mountains, most of copper deposits are typically associated with veins in faulted andesites, granodiorites and diorites or are associated with dikes $[7,8]$.

Despite of northwestern part of UDMA which intrusion of small to intermediate igneous masses caused semicircular alteration zones and forming porphyry deposits, in the Jebal Barez Mountains intruding a huge mass of granite and granodiorites caused more dispersion of ore minerals in a large volume of rocks. Mapped alterations in the region tend to be more linear patterns associated with fractures and faulting (Figure 2), indicate potential 


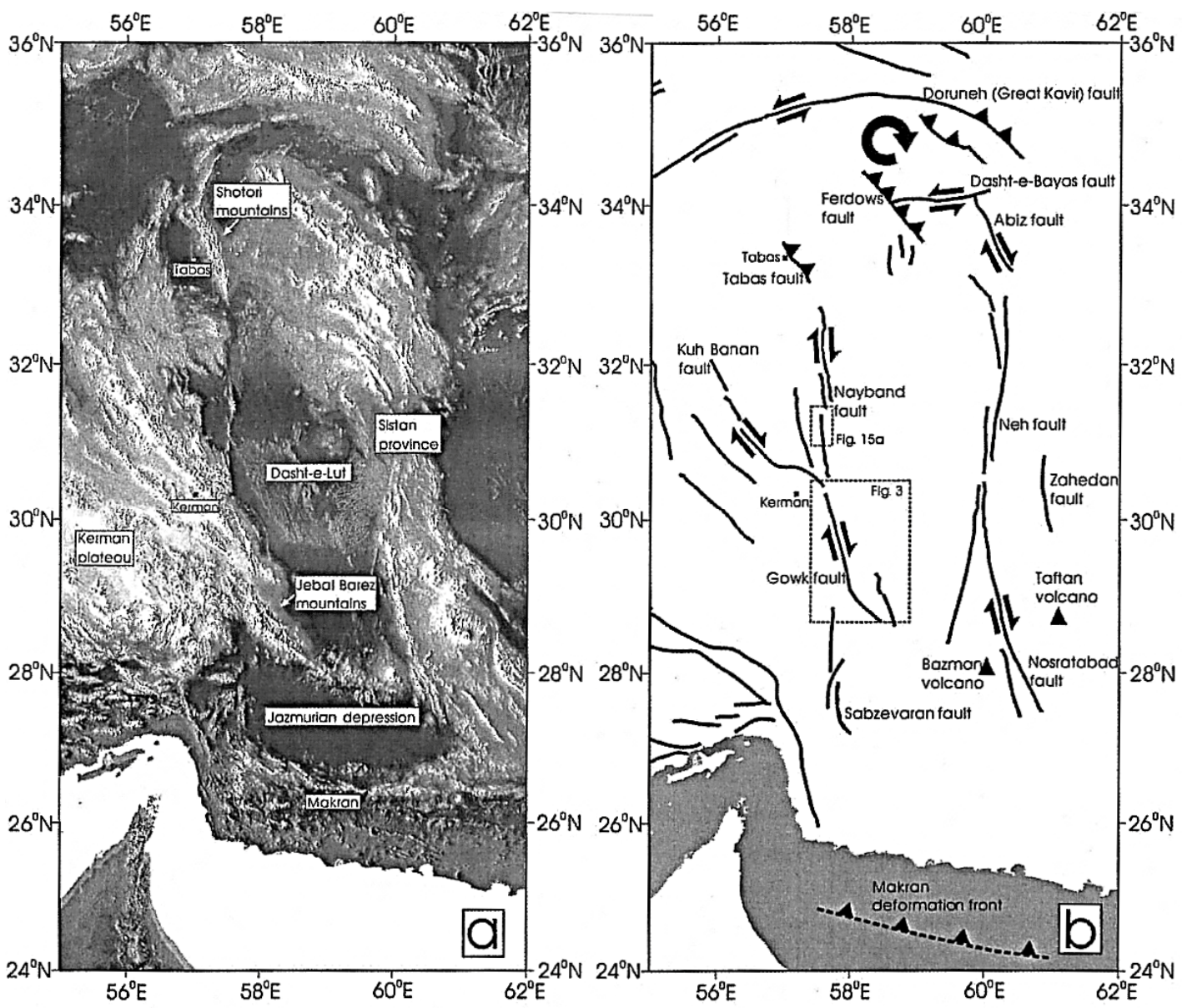

Figure 1. (a) Regional map of eastern Iran; (b) Major faulting in eastern Iran [6].
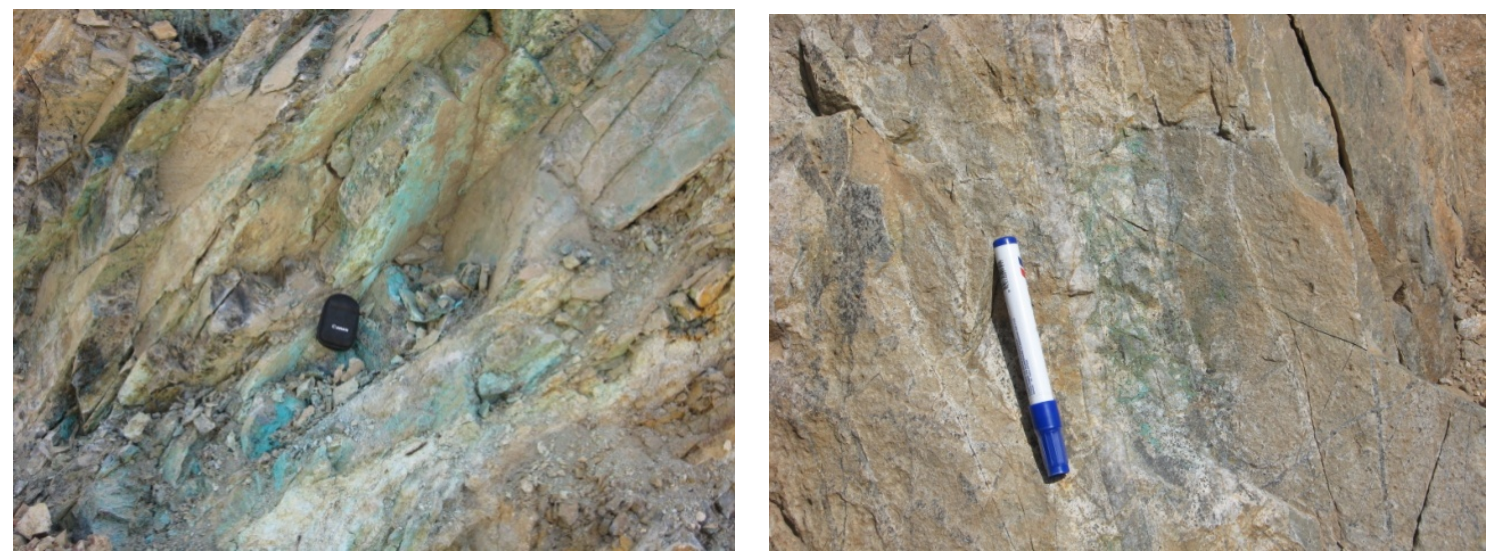

Figure 2. (a) Azurite and malachite forming in fractures; (b) Mineralization in fractures.

for polymetalic or epithermal vein mineralization than porphyry deposits [9].

\section{Definition of Alteration Zones by Using ASTER Data}

An Advanced Spaceborne Thermal Emission and Reflection Radiometer (ASTER), was used in study area to characterize alteration areas related to copper deposits. ASTER images provided preliminary mineralogical information and geo-referenced alteration maps at low cost and with high accuracy [10].

The ASTER consists of three subsystems with a total of 14 bands:

1) The VNIR subsystem by 3 bands obtains optical images ( 0.52 to 0.86 micrometers), with a spatial resolution 
of $15 \mathrm{~m}$.

2) The SWIR subsystem also scans optical images of six bands (1.6 to 2.43 micrometers), with a spatial resolution of $30 \mathrm{~m}$.

3) The TIR subsystem obtains images of five bands (8.125 to 11.65 micrometers), with a spatial resolution of $90 \mathrm{~m}$ [11].

From the nine bands data of VNIR and SWIR set many approaches for the discrimination and mapping of the surface mineral suites have been undertaken. Band ratio transformation was also useful for qualitative detection of alteration minerals [10]. Porphyry copper deposits are typically characterized by zoned assemblages of hydrothermal alteration minerals. These minerals exhibit spectral absorption features in the visible near-infrared (VNIR) and short wave infrared (SWIR) and/or the thermal-infrared (TIR) wavelength regions [12,13].

\section{Logical Operators to Map Argillic and Phyllic Alterations}

Based on laboratory spectra of muscovite, kaolinite and alunite resampled to ASTER band passes (Figure 3), muscovite (in phyllic alteration zone) spectrum display a 2.20 micrometers absorption feature, whereas kaolinite, and alunite (in argillic alteration zone) exhibit 2.17 and

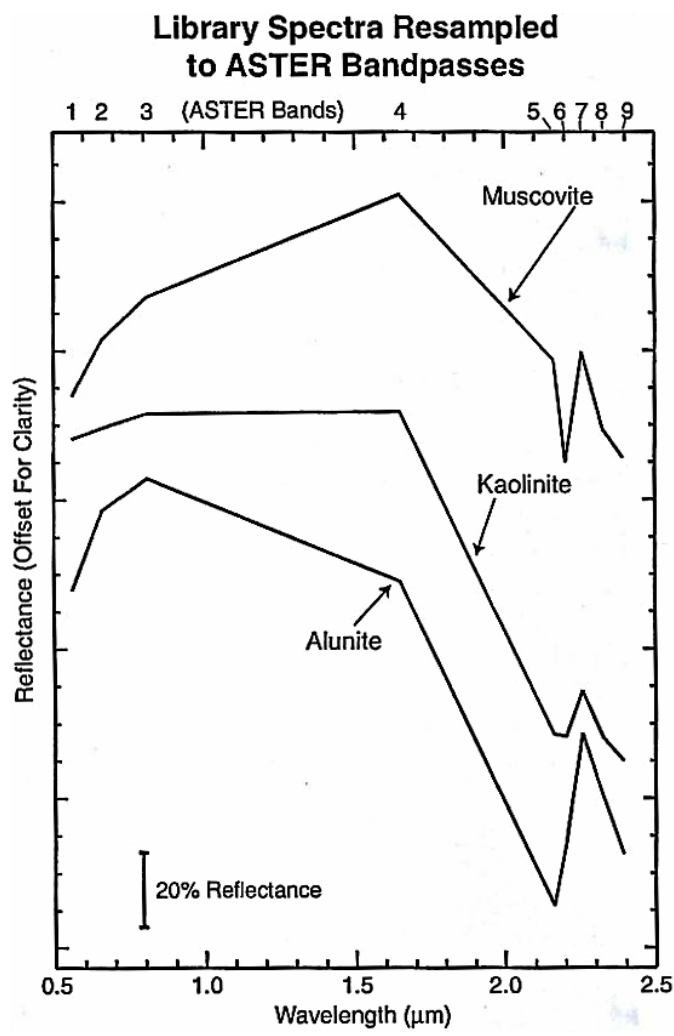

Figure 3. Laboratory spectra of muscovite, kaolinite and alunite resampled to ASTER band pass. The spectra illustrate the position and intensities of absorption features [14].
2.20 micrometers absorption features [14]. FOR qualitative detection of alteration minerals and masking vegetation and dark pixels, logical operators which performed by Mars and Rowan (2006) was used to map alteration zone in study area.

(*1) Logical operator to map argillic alteration [15]:

((float(b3)/b2) and (b4 gt 260) and ((float(b4)/b5) gt 1.25) and ((float(b5)/b6) le 1.05) and ((float(b7)/b6) ge 1.03)

(*2) Logical operator to map phyllic alteration [15]:

((float(b3)/b2) le 1.35) and (b4 gt 260) and ((float(b4)/

b6) gt 1.25) and ((float(b5/b6) gt 1.05) and ((float (b7)/b6) gt 1.03)

Explanation of ENVI operators:

Float: convert to floating point

le: less than or equal to

gt: greater than

ge: greater than or equal to

Images of argillic and phyllic alteration zones are shown on the geological map of study area (Figure 4).

\section{Structural Lineament}

Most of major faults have been mapped by filtering of satellites images in Azimuth directions of 000,045,315 degrees, a RGB image of them is made to increase the width and clarification of linear phenomena on the land. Since roads and some artificial linear objects may confuse with structural lineament, by comparing the RGB image with geological maps and maps of roads, faults of study area are revealed and mapped more accurate (Figure 5).

\section{Photolineament Factor}

Since capability of fluid conduct, along a fault trace is different and it enhanced when two faults crosscutting each others, Hardcastle (1992) method [1] is used to make a contouring map of Photolineament Factor as a data layer. According to this method, a network contains of $10 \times 10$ kilometers quadrangle cells has been designed so that each cell has about 30\% overlap with adjacent cells (Figure 5). Then by using the below Formula, Photolineament Factor is calculated for each cell.

(*3) $\mathrm{PF}=(\mathrm{a} / \mathrm{A})+(\mathrm{b} / \mathrm{B})+(\mathrm{c} / \mathrm{C})+(\mathrm{d} / \mathrm{D})$

In the formula:

"a" is the number of lineaments in each cell and " $\mathrm{A}$ " is average of the number of lineament in whole network.

"b" is the length of lineaments in each cell and " $B$ " is average of the length of lineament in whole network.

" $\mathrm{C}$ " is the intersection number of lineaments in each cell and "C" is average number of intersection of lineament in whole network.

"d" is number of directional sets of lineaments in each cell and " $\mathrm{D}$ " is average number of directional set in 

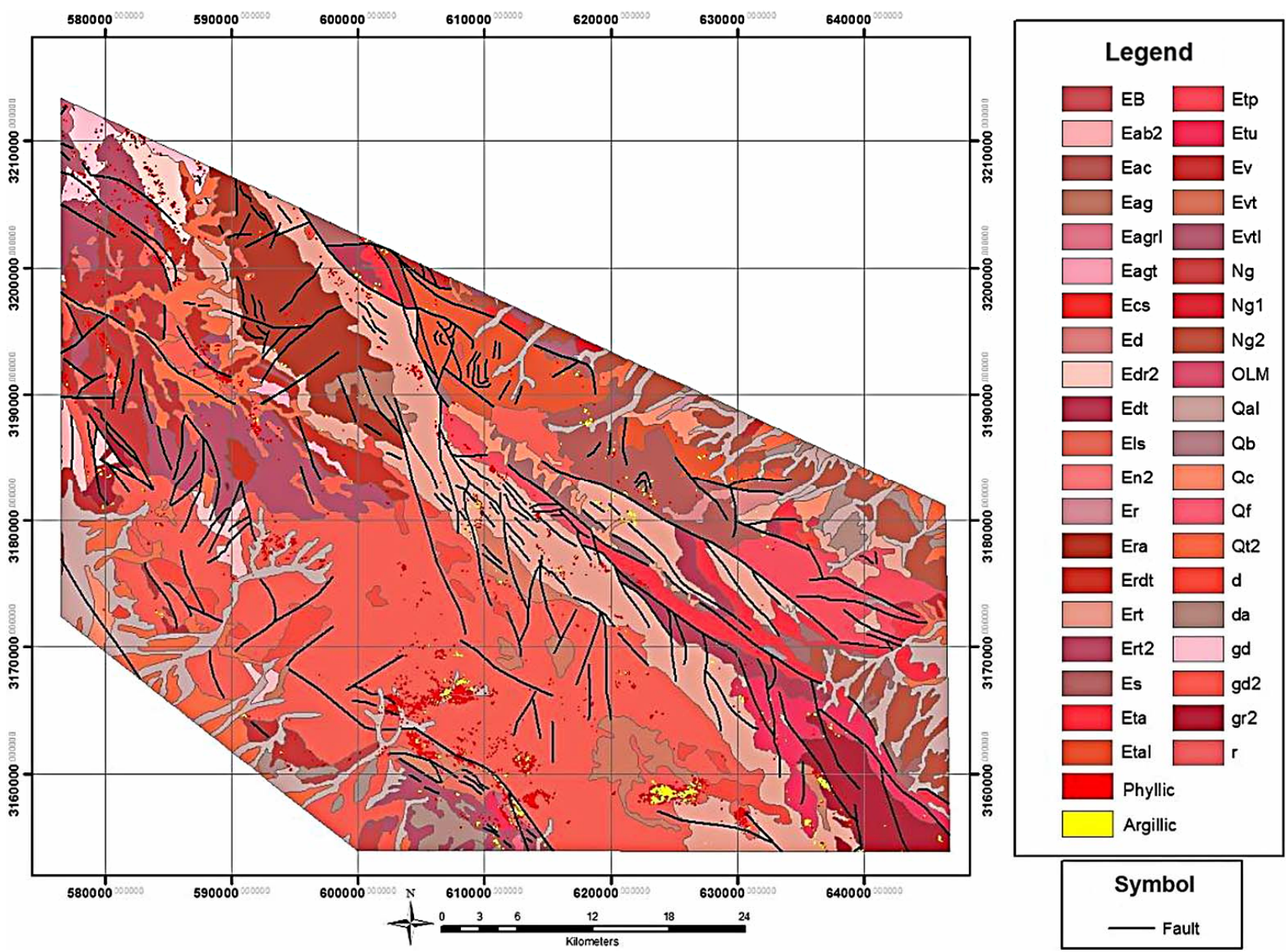

(a)

\section{Appendix}

\begin{tabular}{|c|c|}
\hline EB & Basaltic lava flows \\
\hline Eab2 & Trachyandesite. Basaltic lava flows and pyroclast \\
\hline Eac & Andesite. Daeite. Daeitic Tuff with agglomerate \\
\hline Eag & Bluish green. massive agglomerate \\
\hline Eagrt & Agglomerate and acidic tuff with rare \\
\hline Eagt & Dacitic lava. Tuff. agglomerate \\
\hline Ecs & Red Conglomerate and sandstone \\
\hline Ed & Red dacitic lavas and Tuff \\
\hline Edr2 & Dacite with agglomerate \\
\hline Edt & Green and yellow well bedded dacitic tuff \\
\hline Els & Limestone.Sandstone.Tuff.with middle Eocene nummuli \\
\hline En2 & Limestone. Nummulitic \\
\hline Er & Porphyritic and massive Rhyodacitic \\
\hline Era & Andesitiebasalt.Rhyolite lavas.agglomerate.sandstone a \\
\hline Erdt & Dacitic. Rhyolitic tuff. green. massive \\
\hline Ert & Rhyolitic lavas and pyroclastic sediments with miiddle : \\
\hline Ert2 & Greenich well bedded Tuff.Sandstone and limestone \\
\hline Es & Conglomerate. caleareous sandstone and gypiferrous $n$ \\
\hline Et: & Agglomerate. Tuff. ash \\
\hline & Pinkish Tuff and ash.andesitic Tuff and agg lomerate \\
\hline
\end{tabular}

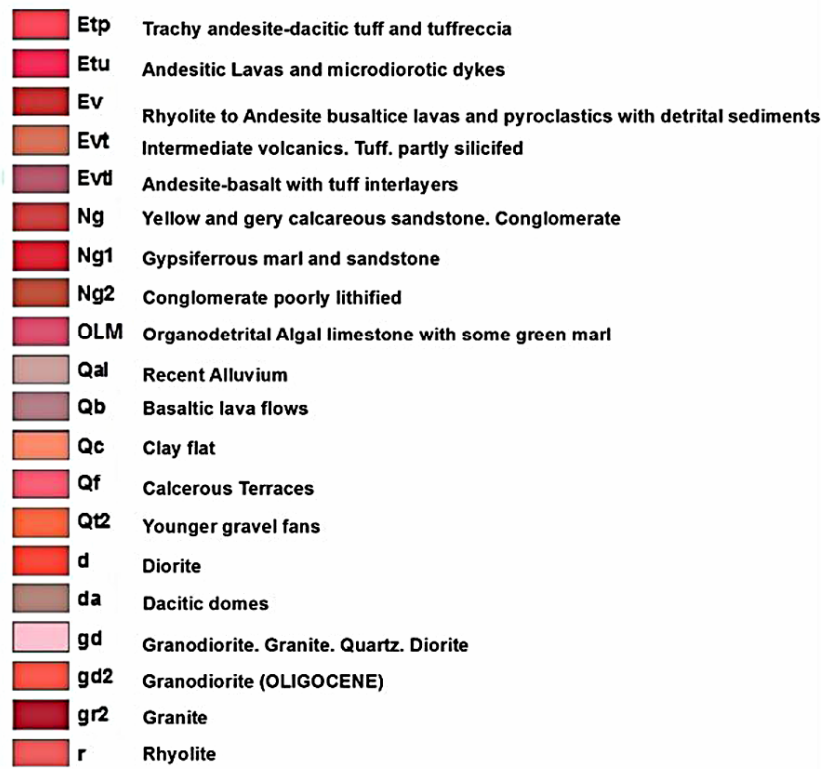

(b)

Figure 4. (a) Phyllic and Argillic alteration zones transferred to geological map; (b) Appendix of geological map. 


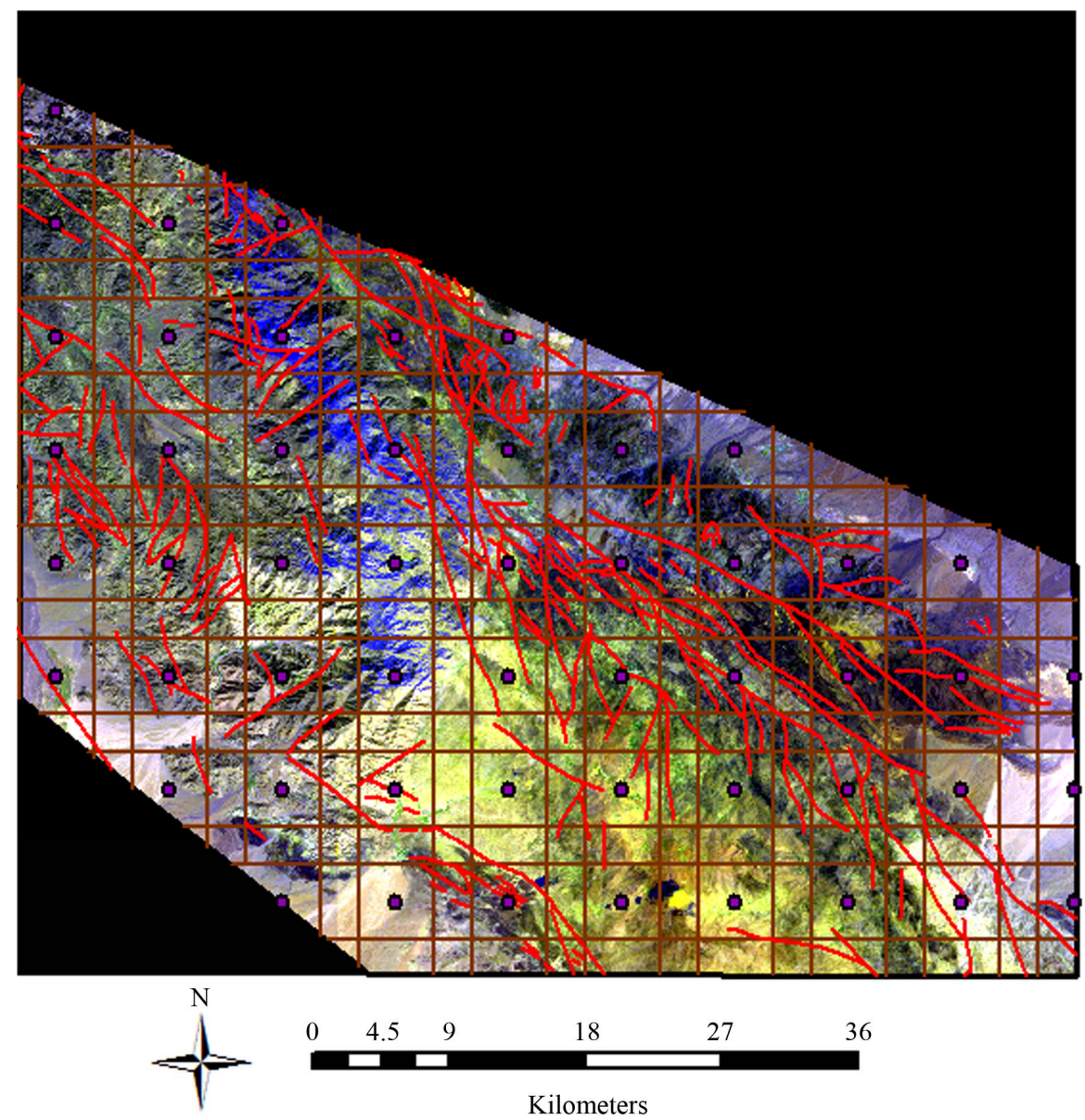

Figure 5. Faults revealed and image of quadrangle cells which designed for statistical studies, transferred to a RGB image of study area.

whole network.

By using calculated PF for each cell a contouring map of PF is made (Figure 6).

\section{Aeromagnetic Data of Study Area}

Recorded Aeromagnetic data with 7.5 kilometers distances of flight lines changed to map of magnetic field Intensity by using reduce to pole method (Figure 7). Previous surveying in UDMA indicated that zones with less Intensity of magnetic field can indicate hydrothermal alteration zones(specially propylitic zones) that probable having copper deposits. It is due to change of magnetic elements of rocks to Fe oxide, because of alteration process [16].

\section{Preliminary Mapping of Copper Potential Deposits by GIS}

Based on digital images and spatial data, some data layers consist of lithology, alterations, faults, aeromagnetic, photolineament factor and locations of known copper deposits, combined together in GIS and a preliminary map of copper potential deposits is made (Figure 8).

\section{Discussion and Conclusions}

Since the study area is very wide, by using remote sensing methods, the locations or area of alteration zones related to copper mineralization have been mapped. Field observation especially in NW of study area indicated copper deposits are typically associated with veins in faulted rocks or are associated with dikes. Many of faults and joints may reinforce the flow of hydrothermal fluids, despite it is hard to make a perfect correlation between high fractures/faults density and copper mineralization at a regional scale $(1: 100,000)$ geological maps, the results are acceptable.

On a regional scale, the low displacement is represented by negligible offset of stratigraphic markers with the fault, appearing as simple fracture. At hand specimen and microscopic scales, the faults may be manifest as a zone of highly fractured rock with no indication of offset [17]. So many of small faults cannot be defined and mapped by satellite images. Faulting and fracturing may enhance fluid flow, whereas high fluid pressure can also 

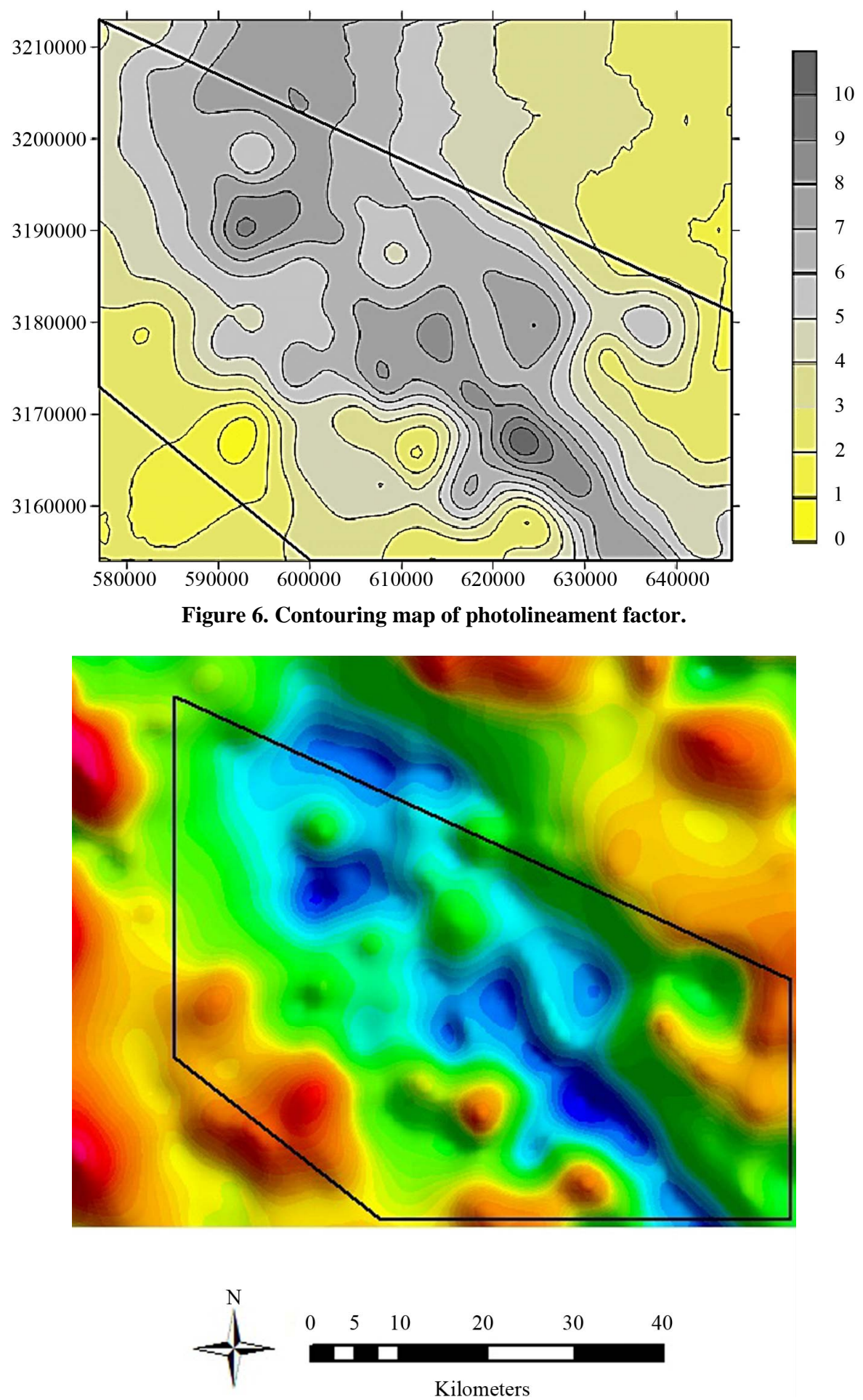

Figure 7. Intensity of magnetic field by using aeromagnetic data (blue colored zones indicate less intensity).

generate crustal faulting and fracture network [18]. On the other hand, in the preexisting faults of a definite plutonic phase, may space creation during faulting be temporary with fault healing by hydrothermal vein precipitation. Faults that behave in this manner are analogous to valves that open and shut and control the flow of fluid during failure and healing [19].

Change of fault geometry, fault-fault intersection and presence of anisotropy such as bedding contact and igneous layering where the contacts are traversed by faults, produce variations in rock properties, which may lead to enhanced fracturing [17]. Hence the rate of fluids flow 


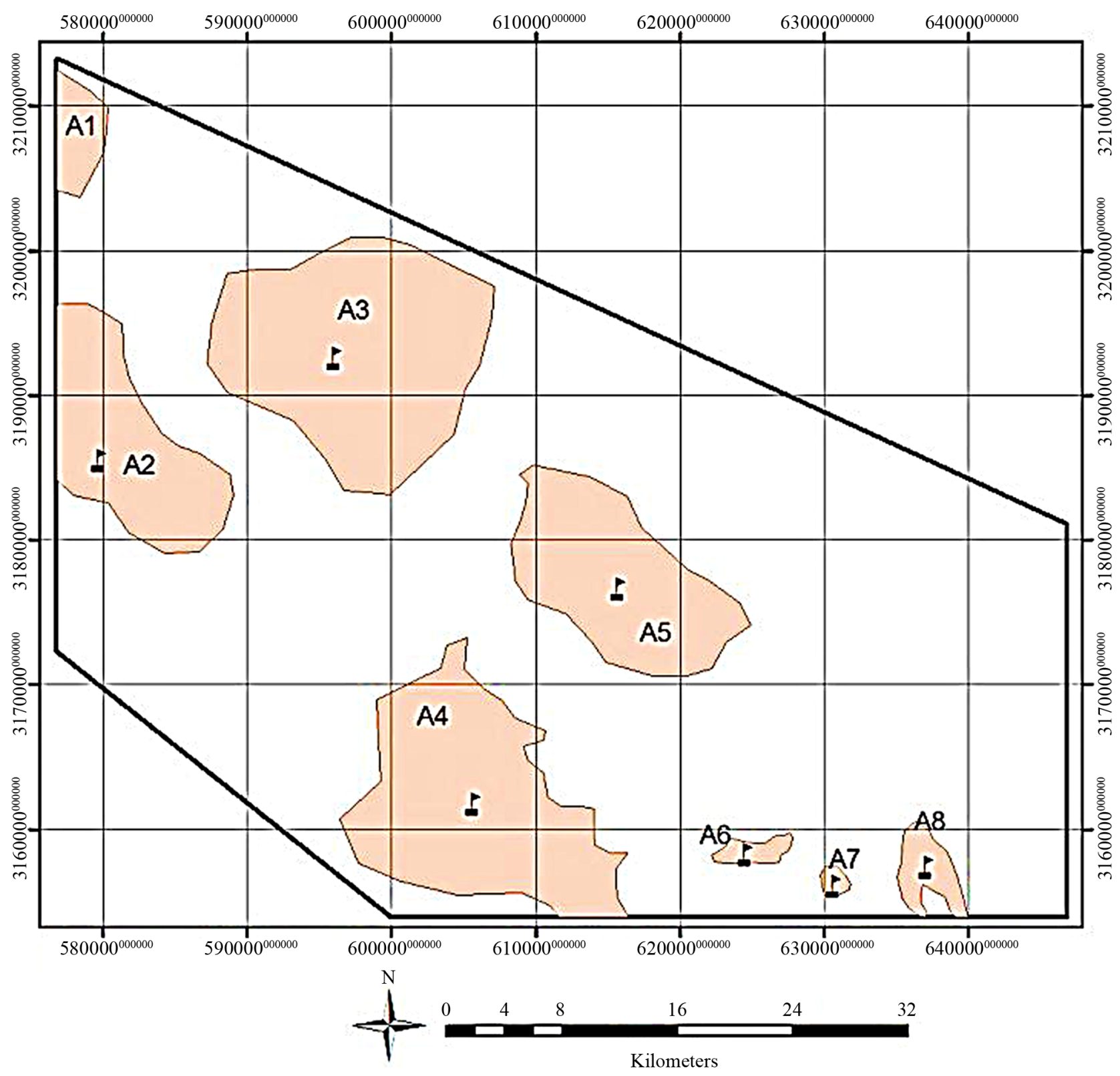

Figure 8. Map of probable copper deposits by combination of data layers in GIS (Flags are locations of known copper deposits).

along a fault may be different and even enhanced along the splays of some faults. Torsion in the wall rocks of splay faults may produce high density fracturing locally [20]. Therefore many of the alteration processes may occur in the space between two parallel or adjacent faults which have noticeable splays. In conclusion because of difference of geometry, kinematic and timing of faults, we don't hope the alteration areas which are defined by spatial images, perfectly coordinate with faults traces in regional scale geological map. We believe that high density of faults and quantity of Photolineament Factor are important factors for preliminary exploration of copper minerals.

\section{Acknowledgements}

This research is part of the Ph.D. thesis of Mohammad Yousef Mahmoodi at Department of Geology, Science and Research Branch, Islamic Azad University. Tehran, Iran. I like to thank Purhabib Mamaghani, R., for digitizing geological map and some software tasks and I am grateful to OJG editorial board and reviewers who helped to improve the previous version of this manuscript.

\section{REFERENCES}

[1] K. C. Hardcastle, "Correlation of Lineament and Fracture Fabric in the Piedmon: Implication for the Study of Frac- 
tured Bedrock Aquifers,” East Geological Society of America, Vol. 24, No. 2, 1992, p. 19.

[2] M. Alavi, "Tectonostratigraphic Evolution of the ZagrosSides of Iran,” Geology, Vol. 8, No. 3, 1980, pp. 144-149. doi:10.1130/0091-7613(1980)8<144:TEOTZO>2.0.CO;2

[3] F. Berberian, I. D. Muir, R. J. Pankurst and M. Berberian, "Late Cretaceous and Early Miocene Andean-Type Plutonic Activity in Northern Makran and Central Iran," Journal of Geological Society of London, Vol. 139, No. 5, 1982, pp. 605-614. doi:10.1144/gsjgs.139.5.0605

[4] S. Dargahi, M. Arvin, Y. Pan and A. Babaei, "Petro Genesis of Post-Coalitional A-Type Granitoids from the Urumieh-Dokhtar Magmatic Assemblage, Southwestern Kerman, Iran: Constraints on the Arabian-Eurasian Continental Collision,” Lithos, Vol. 115, No. 1-4, 2010, pp. 190-204. doi:10.1016/j.lithos.2009.12.002

[5] V. Regard, O. Bellier, J. C. Thomas, M. R. Abbassi, J. Mercier, E. Shabanian, K. Feghhi and S. Soleimani, "Accommodation of Arabia-Eurasia Convergence in the Zagros-Makran Transfer Zone, SE Iran: A Transitional between Collision and Subduction through a Young Deforming System,” Tectonics, Vol. 23, No. 4, 2004, 24p.

[6] R. Walker and J. Jackson, "Offset and Evolution of the Gowk Fault, SE Iran: A Major Intra-Continental StrikeSlip System,” Journal of Structural Geology, Vol. 24, No. 11, 2002, pp. 1677-1698. doi:10.1016/S0191-8141(01)00170-5

[7] V. Grabeljsek, S. Cvetic and M. N. Dimitrijevic, "Geological Map of Iran Sheet 747-Sabzevaran,” Geological Survey of Iran, Tehran, 1972.

[8] N. Valeh, "Geological Map of Iran Sheet 7647 Jebal Barez,” Geological Survey of Iran, Tehran, 1972.

[9] D. P. Cox and D. A. Singer, "Mineral Deposit Models," US Geological Survey Bulletin, Vol. 125, 1963, pp. 145167.

[10] I. Di Tommaso and N. Rubinstein, "Hydrothermal Alteration Mapping Using ASTER Data in the Infernillo Porphyry Deposit, Argentina,” Ore Geology Reviews, Vol. 32, No. 1-2, 2007, pp. 275-290.

[11] H. Fujisada, A. Iwasaki and S. Hara, "ASTER Stereo System Performance,” Proceeding of SPIE, Vol. 4540, International Society for Optical Engineering, Bellingham, 2001, pp. 39-49.

[12] M. J. Abrams, D. Brown, L. Lepley and R. Sadowski,
"Remote Sensing of Porphyry Deposits in Southern Arizona," Economic Geology and the Bulletin of the Society of Economic Geology, Vol. 78, No. 4, 1983, pp. 591-604

[13] D. M. Spatz and R. T. Wilson, "Remote Sensing Characteristics of Porphyry Copper System, Western America Cordillera,” In: F. W. Pierce and J. C. Bolm, Eds., Arizona Geological Society Digest, Vol. 20, Arizona Geological Society, Tucson, 1995, pp. 94-108

[14] R. N. Clark, G. A. Swayze, A. Gallagher, T. V. V. King and W. M. Calvin, "The US Geological Survey, Digital Spectral Library: Version 1:0.2 to 3.0 Microns: US Geological Survey, 1993b,” Open File Report 93-592, 1340p. http//speclab.cr.usgs.usgs.gov

[15] J. C. Mars and L. C. Rowan, "Regional Mapping of Phyllic and Argillic-Altered Rock in the Zagros Magmatic Arc, Iran, Using Advanced Space Borne Thermal Emission and Reflection Radiometer (ASTER) Data and Logical Operator Algorithm,” Journal of Geosphere, Vol. 2, No. 3, 2006, pp. 161-186.

[16] H. Ranjbar, H. Shahriari and M. Honarmand, "Integration of ASTER and Airborne Geophysical Data for Exploration of Copper Mineralization. A Case Study of Sarcheshme Area," 20th International Society for Photogrammetric and Remote Sensing Congress, Istanbul, 12-23 July 2004, pp. 701-706.

[17] J. I. Trippe and J. R. Verncombe, "Fault/Fracture Density and Mineralization: A Contouring Method for Targeting in Gold Exploration,” Journal of Structural Geology, Vol. 26, No. 6-7, 2004, pp. 1087-1108.

[18] R. H. Sibson and J. Scott, "Stress/Fault Controls on the Containment and Release of Over-Pressured Fluids: Examples from Gold-Quartz Vein System in Juneau, Alaska, Victoria, Australia and Otego, New Zealand,” Ore Geology Reviews, Vol. 13, No. 1-5, 1998, pp. 293-306. doi:10.1016/S0169-1368(97)00023-1

[19] R. H. Sibson, F. Robert and K. H. Paulsen, "High Angle Reverse Faults, Fluid-Pressure Cycling and Mesothermal Gold-Quartz Deposits,” Geology, Vol. 16, No. 6, 1988, pp. 551-555. doi:10.1130/0091-7613(1988)016<0551:HARFFP >2.3.C $\underline{\mathrm{O} ; 2}$

[20] S. J. Martel, "Mechanical Controls on Fault Geometry," Journal of Structural Geology, Vol. 21, No. 6, 1999, pp. 585-596. doi:10.1016/S0191-8141(99)00054-1 